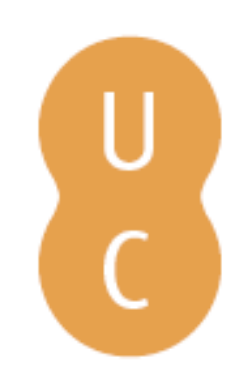

\title{
nombalina
}

\section{An exploratory approach to time perspective theory and research}

\author{
Autor(es): $\quad$ Ortuño, Victor E. C.; Gomes, Catarina V. M.; Paixão, Maria Paula; \\ Janeiro, Isabel Nunes
}

Publicado por: Imprensa da Universidade de Coimbra

URL

persistente: URI:http://hdl.handle.net/10316.2/38631

DOI: $\quad$ DOI:http://dx.doi.org/10.14195/978-989-26-0775-7_27

Accessed : $\quad$ 26-Apr-2023 08:45:18

A navegação consulta e descarregamento dos títulos inseridos nas Bibliotecas Digitais UC Digitalis, UC Pombalina e UC Impactum, pressupõem a aceitação plena e sem reservas dos Termos e Condições de Uso destas Bibliotecas Digitais, disponíveis em https://digitalis.uc.pt/pt-pt/termos.

Conforme exposto nos referidos Termos e Condições de Uso, o descarregamento de títulos de acesso restrito requer uma licença válida de autorização devendo o utilizador aceder ao(s) documento(s) a partir de um endereço de IP da instituição detentora da supramencionada licença.

Ao utilizador é apenas permitido o descarregamento para uso pessoal, pelo que o emprego do(s) título(s) descarregado(s) para outro fim, designadamente comercial, carece de autorização do respetivo autor ou editor da obra.

Na medida em que todas as obras da UC Digitalis se encontram protegidas pelo Código do Direito de Autor e Direitos Conexos e demais legislação aplicável, toda a cópia, parcial ou total, deste documento, nos casos em que é legalmente admitida, deverá conter ou fazer-se acompanhar por este aviso.

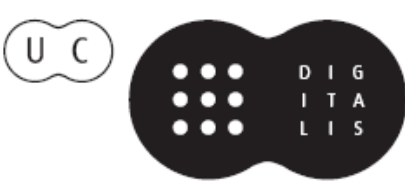




\section{INTERNATIONAL \\ STUDIES IN TIME \\ PERSPECTIVE}

MARIA PAULA PAIXÃO

JOSÉ TOMÁS DA SILVA

(COORD.)

VICTOR ORTUÑO

PEDRO CORDEIRO

(EDITORS)

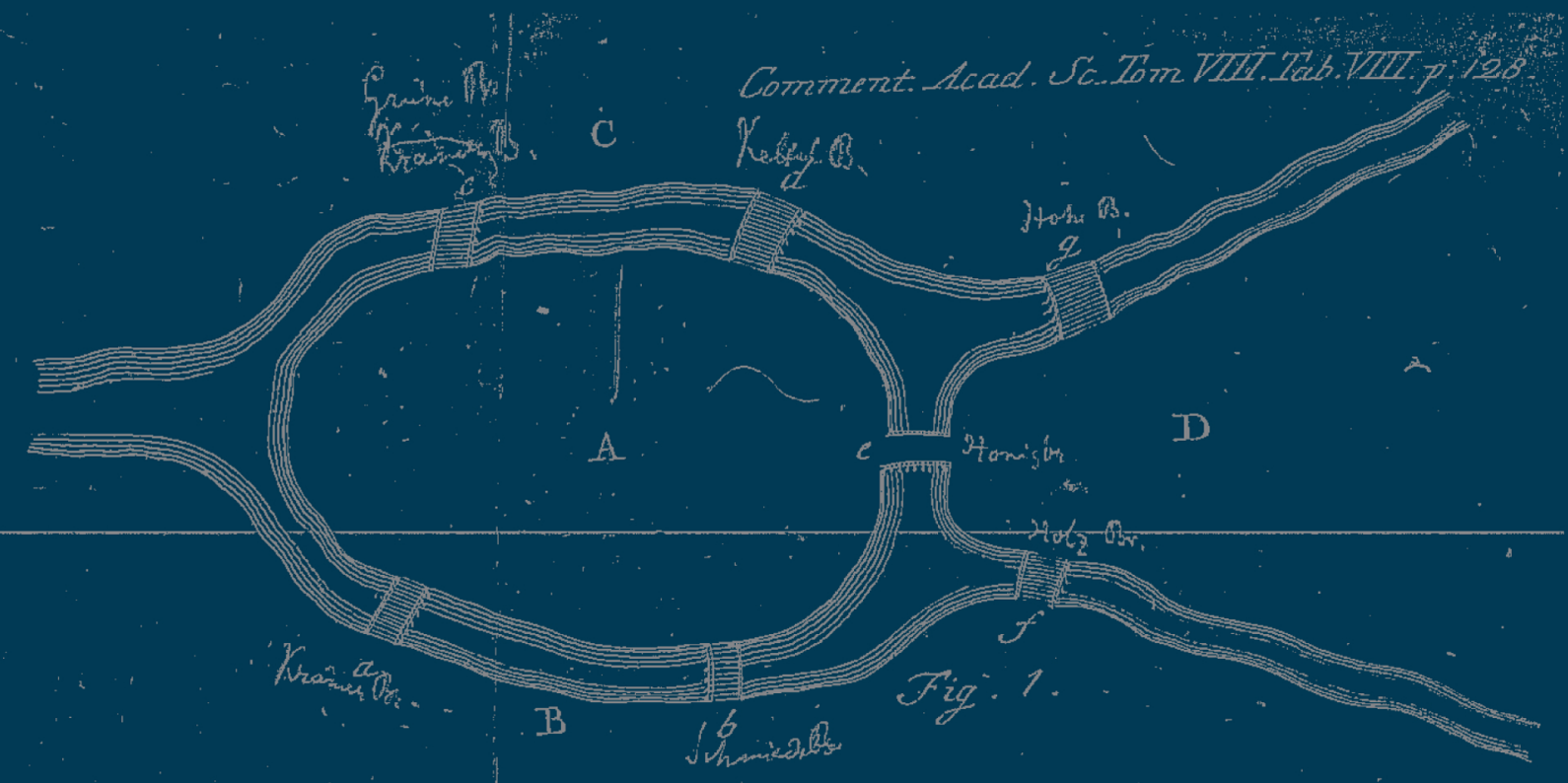

IMPRENSA DA

UNIVERSIDADE

DE COIMBRA

COIMBRA

UNIVERSITY

PRESS 
Chapter 27

An eXPloratory approach to Time Perspective

THEORY AND RESEARCH

Victor E. C. Ortuño

Faculty of Psychology and Educational Sciences, University of Coimbra, Portugal

victortuno@gmail.com

Catarina V. M. Gomes

Independent Practice, Porto, Portugal

Maria Paula Paixão

Faculty of Psychology and Educational Sciences, University of Coimbra, Portugal

Isabel Nunes Janeiro

Faculty of Psychology, University of Lisbon, Portugal

Aвsтract: The Time Perspective theoretical model proposed by Zimbardo \& Boyd (1999) has been very prolific in the quantity and quality of research produced in the last decade. However, taking into account the definition of time perspective of Kurt Lewin (1951), we believe that a negative future dimension is an important component of the individual's time perspective. The objective of this study is to verify a 7-dimension model of Time Perspective formed by the 5 original dimensions of the Zimbardo Time Perspective Inventory - ZTPI (Zimbardo \& Boyd, 1999), the TranscendentalFuture from Transcendental-Future Time Perspective Scale - TFTPS (Boyd \& Zimbardo, 1997) and the Negative Future Scale from Inventário de Perspectiva Temporal - IPT (Janeiro, 2012) in a sample of 563 Portuguese college students. Through Exploratory Factor Analysis we found evidence that supports this model. The majority of items load above .30 in their respective factors, the internal consistency of the 7 dimensions ranges from .722 to .865 and the total variance explained is $46.18 \%$.

Keywords: time perspective, motivation, negative future, ZTPI, exploratory factor analysis.

\section{INTRODUCTION}

Regardless of the theoretical approach, time has been pointed to on numerous occasions as a relevant dimension for human behavioural analysis. With Philosophy, it is possible to consider time as a structural component of human thoughts and behaviours (Kant, 1781/1965).

With the work of Kurt Lewin (1951), we can understand that individuals create meanings about the present, but also about the past and future moments, and that these same meanings affect their thinking and behaviour. Therefore, how we evaluate our past and future also influences our hopes, desires, fears, and consequently our behaviour. Thus, Lewin 
(1951) introduced the concept of Temporal Perspective as "the totality of the individual's views of his psychological future and psychological past existing at a given time" (pp. 75).

At present, one of the most widely used theoretical references for the research of time is the one proposed by Zimbardo and Boyd (1999). Continuing the thought of Lewin, these authors argue that Time Perspective is an unconscious process that assists individuals to encode, store and retrieve information related to personal and social objects that fill their life; this process makes it possible to bring order, meaning and coherence to these same objects through various time categories, which also allow a reinterpretation of all this information.

This model is originally composed of 5 temporal dimensions, Past Positive, Past Negative, Present Hedonist, Present Fatalist and Future. Boyd and Zimbardo (2008) introduced a further sixth temporal dimension: The Trancendental-Future Time Perspective, related with the cognitions about the future after the death of the physical body. Yet, it is important to consider that in Lewin's definition of Time Perspective, he considers the effect of fears and anxiety on human behaviour and cognition. Taking this into account, it was decided to add a seventh temporal dimension to the study. The Future Negative (or Anxious Future) relates to negative feelings and an external and instable control locus about the future.

The goal of this study is to test a model of Time Perspective, which includes these 7 temporal dimensions.

\section{Method}

\section{Participants}

Composed of 563 participants with ages between 17 and 54 years old ( $M=20,15$, S.D. $=4.24) .511(91.7 \%)$ are female and $46(8.3 \%)$ male. The participants are students from the Faculty of Psychology and Educational Sciences of the University of Coimbra. 496 (88.7\%) attend the Integrated Master in Psychology, 13 (2.3\%) the Master in Educational Sciences and $47(8.4 \%)$ the Social Work Undergraduate Degree.

\section{Instruments}

All the data were collected using 4 instruments: a Socio-Demographic Questionnaire, the Portuguese Zimbardo Time Perspective Inventory - ZTPI (Zimbardo \& Boyd, 1999; Ortuño \& Gamboa, 2009), the Portuguese Transcendental-Future Time Perspective Scale - TFTPS (Boyd \& Zimbardo, 1997; Ortuño, Paixão \& Janeiro, in press) and the Future Negative Subscale of the Inventário de Perspectiva Temporal - IPT (Janeiro, 2012).

Socio-Demographic Questionnaire: Drawn up by the authors in order to characterize the sample (age, sex, course, course year, etc.).

Zimbardo Time Perspective Inventory - ZTPI (Zimbardo \& Boyd, 1999; Ortuño \& Gamboa, 2009): this is composed by 56 items (5-point Likert scale) in its Portuguese version (Ortuño \& Gamboa, 2009) which represents 5 temporal dimensions: 1) Past Positive, related to pleasant and warm attitudes towards the past (explained variance = $6.02 \%, \alpha=.68,9$ items), 2) Past Negative, represents an aversive and distressful attitude towards the past (variance explained $=7.85 \%, \alpha=.80,10$ items), 3) Present Hedonist, represents a tendency to seek immediate pleasure, through exciting and risky experiences 
(explained variance $=8.37 \%, \alpha=.79,15$ items), 4) Present Fatalist, shows a totally defeatist attitude towards life (explained variance $=6.42 \%, \alpha=.66,9$ items) and 5) Future, indicates a strong tendency to create and pursue long term objectives (variance explained $=6.57 \%$, $\alpha=.74,13$ items). These 5 temporal dimensions explain $35.25 \%$ of the total variance and a test/re-test validity values between .66 and .86 .

Transcendental-Future Time Perspective Scale - TFTPS (Boyd \& Zimbardo, 1997; Ortuño, Paixão \& Janeiro, in press): this is a one-dimension scale, formed by 10 items (5-point Likert scale). Evaluates the individual's beliefs and attitudes about the future after the death of the physical body. The original TFTPS explains $10 \%$ of the total variance, with a internal consistency of .87 and a test/re-test stability of .86 .

Inventário de Perspectiva Temporal - IPT (Janeiro, 2012): this is formed by 32 items (7-point Likert-type scale), grouped in 4 temporal dimensions: 1) Past Orientation, 2) Present Orientation, 3) Future Orientation and 4) Negative Future. In this study we used only 4 items related with the negative future dimension (variance explained $=8 \%, \alpha=.70$, 4 items) which is related to an unpredictable and threatening vision of events yet to come.

\section{Procedures \& Statistical Analyses}

All the data were collected in classrooms. The responses were standardized and any values higher than 2.5 or lower than -2.5 were considered outliers. An Exploratory Factor Analysis - EFA was performed using the 56 ZTPI items, 9 items of TFTPS (Item No 5 was eliminated since it presents conceptual and statistical problems in this sample) and 4 items of the IPT (regarding the Future Negative sub-scale). The EFA extraction method was principal component analysis, with Varimax Rotation and fixed to 7 factors. The missing values were replaced with the mean item value.

All the collected data was introduced in the statistical program Statistical Package for the Social Sciences - SPPS 16.0 (Windows version).

\section{Results}

\section{Exploratory Factor Analysis}

The total variance explained by the seven factors was $46.18 \%$. The KMO index for sample adequacy was .894 and the Bartlett's Test of Sphericity value was significant $(p<$ 001). 62 of the 69 items used in the EFA exhibit loadings higher than .30 in the correct factor. The first factor encountered was Present Hedonist with $9.18 \%$ of explained variance. The second factor was Future with $8.28 \%$. The third was Past Negative, with $7.92 \%$. The fourth was Transcendental-Future, with 7.18\%. The fifth was Past Positive, with $4.93 \%$. The sixth was Future Negative, with $4.41 \%$ and the seventh was Present Fatalist, with $4.30 \%$ of explained variance.

\section{Internal Consistency}

The results of Cronbach's alpha for the 7 factors ranged from .746 to .865 (see Table 1 ). None of the items' removal represents a substantial improvement of those values. 
Table 1 - Exploratory Factor Analysis of the 7 Dimensions Time Perspective Model (ZTPI, TFTPS \& IPT)

\begin{tabular}{|c|c|c|c|c|c|c|c|c|c|c|c|}
\hline $\begin{array}{l}\text { Dimensions } \\
(\text { Cronbach's } \alpha)\end{array}$ & Items & PH & $\mathrm{F}$ & PN & $\mathrm{TF}$ & PP & $\mathrm{FN}$ & $\mathrm{PF}$ & $\mathrm{M}$ & DP & $\begin{array}{c}\alpha \text { without } \\
\text { item }\end{array}$ \\
\hline \multirow{15}{*}{$\begin{array}{l}\text { Present Hedonist (PH) } \\
(\alpha=.852)\end{array}$} & 31 & .668 & & & & & & & 2.89 & .94 & .835 \\
\hline & 42 & .635 & & & & & & & 2.63 & 1.05 & .845 \\
\hline & 23 & .623 & & & & & & & 2.99 & .92 & .841 \\
\hline & 46 & .619 & & & & & & & 3.38 & .96 & .838 \\
\hline & 32 & .618 & & & & & & & 3.57 & .97 & .836 \\
\hline & 26 & .606 & .405 & & & & & & 3.92 & .93 & .834 \\
\hline & 48 & .560 & .336 & & & & & & 3.68 & .98 & .839 \\
\hline & 44 & .553 & & & & & & & 3.19 & 1.04 & .840 \\
\hline & 8 & .533 & & & & & & & 3.04 & .97 & .845 \\
\hline & 19 & 466. & & & & & & & 3.59 & 1.11 & .847 \\
\hline & 28 & 459. & & & & & & & 3.0 & 1.04 & .848 \\
\hline & 12 & .438 & .319 & & & & & & 3.61 & 1.06 & .842 \\
\hline & 17 & .436 & & & & & -.332 & & 3.97 & .85 & .846 \\
\hline & 1 & .529 & .581 & & & & & & 4.1 & 1.16 & .835 \\
\hline & 55 & & & & & & & -.318 & 4.23 & .74 & .864 \\
\hline \multirow{13}{*}{$\begin{array}{l}\text { Future }(F) \\
(\alpha=.746)\end{array}$} & 10 & .354 & .711 & & & & & & 3.83 & .88 & .715 \\
\hline & 30 & & .709 & & & & & & 3.73 & .89 & .709 \\
\hline & 45 & & .697 & & & & & & 3.38 & .97 & .711 \\
\hline & 18 & & .680 & & & & & & 3.94 & 1.02 & .711 \\
\hline & 40 & & .677 & & & & & & 3.63 & .88 & .715 \\
\hline & 13 & & .648 & & & & & & 3.85 & 1.02 & .713 \\
\hline & 51 & & .632 & & & & & & 3.39 & .90 & .719 \\
\hline & 21 & & .512 & & & & & & 3.95 & .72 & .729 \\
\hline & 43 & & .354 & & & & & & 3.05 & 1.26 & .732 \\
\hline & 9 & & & & & & & -.259 & 4.04 & 1.11 & .747 \\
\hline & 24 & -.553 & & & & & & -.402 & 3 & 1.01 & .764 \\
\hline & 56 & -.359 & & & & & & & 3.29 & .92 & .764 \\
\hline & 6 & & & & & & .303 & & 2.41 & 1.25 & .752 \\
\hline \multirow{10}{*}{$\begin{array}{l}\text { Past Negative (PN) } \\
(\alpha=.843)\end{array}$} & 50 & & & .767 & & & & & 2.46 & 1.06 & .812 \\
\hline & 16 & & & .739 & & & & & 2.60 & 1.07 & .814 \\
\hline & 34 & & & .712 & & & & & 2.41 & 1.10 & .819 \\
\hline & 27 & & & .657 & & & & & 3.07 & 1.244 & .826 \\
\hline & 54 & & & .629 & & & & & 2.72 & 1.11 & .820 \\
\hline & 22 & & & .583 & & -.339 & & & 1.97 & 1.12 & .835 \\
\hline & 4 & & & .565 & & & & & 3.47 & .97 & .834 \\
\hline & 36 & & & .550 & & & & & 2.71 & 1.09 & .828 \\
\hline & 33 & & & .366 & & & & .303 & 2.72 & .87 & .838 \\
\hline & 5 & & & & & & .289 & & 2.78 & .92 & .852 \\
\hline
\end{tabular}




\begin{tabular}{|c|c|c|c|c|c|c|c|c|c|c|c|}
\hline $\begin{array}{l}\text { Dimensions } \\
\text { (Cronbach's } \alpha \text { ) }\end{array}$ & Items & PH & $\mathrm{F}$ & PN & TF & PP & FN & $\mathrm{PF}$ & M & DP & $\begin{array}{c}\alpha \text { without } \\
\text { item }\end{array}$ \\
\hline \multirow{9}{*}{$\begin{array}{l}\text { Transcendental-Future } \\
\text { (TF) } \\
(\alpha=.865)\end{array}$} & 3 & & & & .809 & & & & 2.64 & 1.224 & .838 \\
\hline & 1 & & .307 & & .739 & & & & 2.85 & 1.32 & .840 \\
\hline & 2 & & & & .729 & & & & 2.58 & 1.26 & .842 \\
\hline & 4 & & & & .694 & & & & 2.35 & 1.13 & .851 \\
\hline & 9 & & & & .684 & & & & 2.32 & 1.12 & .851 \\
\hline & 10 & & & & .682 & & & & 2.46 & 1.23 & .854 \\
\hline & 8 & & & & .678 & & & & 2.41 & 1.16 & .851 \\
\hline & 6 & & & & .671 & & & & 3.49 & 1.18 & .843 \\
\hline & 7 & .393 & & & .442 & & & & 3.71 & 1.09 & .858 \\
\hline \multirow{9}{*}{$\begin{array}{l}\text { Past Positive (PP) } \\
(\alpha=.765)\end{array}$} & 15 & & & & & .611 & & & 3.39 & 1.07 & .726 \\
\hline & 49 & & & & & .591 & & & 3.75 & .99 & .748 \\
\hline & 7 & & & & & .590 & & & 3.07 & .98 & .728 \\
\hline & 41 & & & & & .536 & & & 3.97 & .92 & .761 \\
\hline & 20 & .305 & & & & .477 & & & 3.81 & .94 & .734 \\
\hline & 29 & & & & & .455 & & & 3.20 & 1.16 & .754 \\
\hline & 11 & .362 & & -.376 & & .406 & & & 3.71 & 1.04 & .738 \\
\hline & 2 & .355 & .485 & & & .462 & & & 3.82 & .99 & .724 \\
\hline & 25 & & & -.639 & & .437 & & & 4 & 99 & .769 \\
\hline \multirow{4}{*}{$\begin{array}{l}\text { Future Negative (FN) } \\
(\alpha=.858)\end{array}$} & 27 & & & .362 & & & .654 & & 2.06 & 1.46 & .792 \\
\hline & 09 & & & .332 & & & .651 & & 2.01 & 1.4 & .803 \\
\hline & 16 & & & .307 & & & .645 & & 2.50 & 1.6 & .813 \\
\hline & 05 & & & & & & .631 & & 2.27 & 1.51 & .866 \\
\hline \multirow{9}{*}{$\begin{array}{l}\text { Present Fatalist (PF) } \\
(\alpha=.722)\end{array}$} & 39 & & & & & & & .645 & 1.92 & .935 & .688 \\
\hline & 14 & & & & & & & .583 & 2.42 & 1.02 & .692 \\
\hline & 53 & & & & & & & .527 & 2.14 & .981 & .694 \\
\hline & 37 & .355 & & .315 & & & & .496 & 3.03 & 1.06 & .672 \\
\hline & 38 & & & .338 & & & & .481 & 2.15 & .96 & .683 \\
\hline & 52 & & & & & & & .306 & 2.23 & 1.01 & .721 \\
\hline & 35 & & & & & & & .302 & 2.43 & .90 & .700 \\
\hline & 3 & & & & .326 & & & .324 & 2.56 & .97 & .711 \\
\hline & 47 & & & & & .324 & .303 & & 2.49 & 1.05 & .713 \\
\hline
\end{tabular}

\section{Discussion}

The results of this exploratory attempt to improve the study of Time Perspective were satisfactory. The proposed model was confirmed by a clear factor structure with high loadings and good internal consistency across the 7 temporal dimensions. The KMO index and Bartlett's Test results were also satisfactory. With these results we would like to show the possibility of developing the 5-dimension TP model even further. We believe that the Negative Future and Transcendental-Future Temporal Perspectives can bring an important 
understanding of human behaviour. As Ortuño, Paixão \& Janeiro (2011 - February) point out, Negative Future Time Perspective can significantly contribute to explaining SelfEsteem, for the two are negatively related. Regarding Transcendental-Future, in a crosssectional study with a sample of college students, Ortuño, Paixão e Janeiro (2011a) noticed that the mean scores of the TFTP lowered as the students advanced in their academic courses. The same authors (2011b) also found significant differences between religious and non religious students, noticing that religious students show higher scores of TFTP. Thus, we recommend the addition of these two temporal dimensions for future researches on the subject of Time Perspective.

\section{REFERENCES}

Boyd, J. N., Zimbardo, P. G. (1997). Constructing time after death: The transcendental future time perspective. Time and Society, 6(1), 35-54.

Janeiro, I. N. (2012). O Inventário de Perspectiva Temporal: Estudo de validação. Revista Iberoamericana de Diagnóstico e Avaliação Psicológica, 34, 117 - 133.

Kant, I. (1965). Critique of pure reason (N. Smith, Trans.). New York: St. Martin's Press. (Original work published 1781).

LEwIN. K. (1951). Field theory in the social sciences: Selected theoretical papers. New York: Harper.

Ortuño, V. E. \& Gamboa, V. M. (2009). Estrutura factorial do Zimbardo Time Perspective Inventory - ZTPI numa amostra de estudantes universitários portugueses. Avances en Psicología Latinoamericana, 27(1), 21-32.

Ortuño, V. E., Paixão, M. P. \& Janeiro, I. N. (in press). Tempus Post Mortem? Adaptação Portuguesa da Transcendental-Future Time Perspective Scale - TFTPS. Avances en Psicologia Latinoamericana.

Ortuño, V., Paixão, M. P. \& Janeiro, I. (2011 - February) O tempo subjectivo como instrumento instrumento (des)adaptativo no processo desenvolvimental. In: Dias, M. \& Franco-Borges, G. (Coords.), O Desenvolvimento de Trajectórias (in)Adaptativas: Factores Pessoais, Familiares e Sociais. Symposium presented at 1st International Congress of Development Psychology, Lisbon: ISPA.

Ortuño, V., Paixão, M. P. \& Janeiro, I. (2011a). Tempo e Universidade: A Evolução da Perspectiva Temporal ao Longo do Percurso Universitário. In Faria, L., Araújo, A., Morais, F., Sá, E., Pinto, J. \& Silva, A., Carreira, Criatividade e Empreendedorismo (pp 217-225). Braga: APDC Ediçôes.

Ortuño, V., Paixão, M. P. \& Janeiro, I. (2011b). Diferenças na Perspectiva Temporal entre estudantes religiosos e não religiosos. Proceedings of VIII Congresso Iberoamericano de Avaliação Psicológica, Lisbon: University of Lisbon.

Zimbardo, P. G. \& Boyd, J. N. (1999). Putting time in perspective: A valid, reliable individual differences metric. Journal of Personality and Social Psychology, 77, 1271-1288.

Zimbardo, P. G., \& Boyd, J. N. (2008). The Time Paradox: Using the New Psychology of Time to Your Advantage. London: Rider. 